\title{
The Use of Different Aspects of the Deuteronomistic Ideology in Apocryphal Psalms
}

\section{Pajunen, Mika}

de Gruyter

2011

Pajunen, M 2011, The Use of Different Aspects of the Deuteronomistic Ideology in Apocryphal Psalms . in J Pakkala, M Marttila \& H von Weissenberg (eds), Changes in Scripture : Rewriting and Interpreting Authoritative Traditions in the Second Temple Period . Beihefte zur Zeitschrift für die alttestamentliche Wissenschaft, no. 419 , de Gruyter , Berlin , pp. 347-367 .

http://hdl.handle.net/10138/231809

publishedVersion

Downloaded from Helda, University of Helsinki institutional repository.

This is an electronic reprint of the original article.

This reprint may differ from the original in pagination and typographic detail.

Please cite the original version. 


\title{
The Use of Different Aspects of the Deuteronomistic Ideology in Apocryphal Psalms
}

\author{
Mika S. Pajunen
}

A number of studies have dealt with the links between the Psalms of the Masoretic Psalter and the Deuteronomistic ideology. 1 These have shown that there are phraseological links between many Psalms and Deuteronomistic passages of other parts of the Hebrew Bible. However, many psalms that may have been on the fringes of the eventual canonical book of Psalms are left out of these studies at least partly because of this later boundary marking. Such a division is not self-evident in the centuries before the Common Era nor is it in accordance with the available sources. Already the Septugint and Syriac manuscripts have provided several additional psalms in comparison to the MT, viz., Psalms 151-155, but the Qumran finds make the issue more poignant. In addition to Hebrew versions for many of these already known apocryphal psalms, a number of new psalms, put in the same collections with now canonical psalms were found, cf. 4QPsf, 11QPsatb and 11QapocrPs. The manuscripts from Qumran also provided a number of psalm collections that yielded (in their extant parts) only previously unknown psalm compositions, e.g., 4QNon-Canonical Psalms A+B (4Q380-381) and 4QBarkhi Nafshia-e (4Q434-438). Thus, in order to gain a more comprehensive picture of how broadly spread the Deuteronomistic influence is in psalm compositions a survey of the psalms now designated as 'apocryphal' will be done. This analysis will hopefully be able to offer further useful insights into this phenomenon. The purpose of this article is to map out the extent to which the so-called Deuteronomistic ideology has influenced these psalms.

The first issue to be dealt with is the question of definitions, namely, what exactly is, in this article, included under the designation "apocryphal psalms" and what is sought when looking for traces of "Deute-

1 See, e.g., Timo Veijola, Verheissung in der Krise: Studien zur Literatur und Theologie der Exilszeit anhand des 89. Psalms, (AASF B 220; Helsinki: Suomalainen Tiedeakatemia, 1982); Harry P. Nasuti, Tradition History and the Psalms of Asaph (SBLDS 88; Atlanta: Scholars Press, 1988). 
ronomistic ideology". Neither of these questions has an easy answer as each task is quite challenging and, especially in the case of the psalms, in a way artificial. When looking at the wealth of poetic material found at Qumran and the collections they are put in, it has come quite obvious that making a boundary between Psalms and apocryphal compositions is arbitrary. ${ }^{2}$ Nevertheless for the purposes of this article some criteria are necessary for narrowing down the material, and therefore apocryphal psalms are here seen as poetic compositions that resemble the Psalms now in the MT Psalter and as such may have been on the fringes of the eventual canon. This means that the Psalms of the MT Psalter are not part of this survey and the songs most likely deriving from the Qumran movement are also excluded. The latter are left out because there is no indication that they would have had a status among a wider audience and furthermore they always seem to be placed in their own collections (see, e.g., the Hodayot, ${ }^{3}$ the Songs of the Sage [4Q510-511], etc.), which seems to reflect a conscious decision not to mix them with the earlier Psalms. ${ }^{4}$

Included in this study are the apocryphal compositions within psalm collections that also feature Psalms that are now in the MT Psalter. This means that the altogether nine apocryphal psalms found in the Psalms manuscripts $4 \mathrm{QPs} \mathrm{s}^{\mathrm{f}}$ and 11QPsa+b, 5 as well as the psalms found as parts of a ritual of exorcism (11QapocrPs) that ends with MT Psalm 91, ${ }^{6}$

2 To be sure, many of the apocryphal compositions are later than most of the Psalms, but that is not always the case and some late Psalms like 105 and 106 were most likely composed later than some of the apocryphal pieces. Therefore, while the distinction is sometimes necessary for limiting the material, it unfortunately serves many times as a needless barrier.

3 Deuteronomistic influence in the Hodayot has been dealt with in several studies; see, e.g., Sarah Tanzer, The Sages at Qumran: Wisdom in the Dead Sea Scrolls (Ph.D. diss., University of Harvard, 1987), 144-45, 151-54.

4 Attention can also be drawn to the fact that even though 1QS and 1QM incorporate songs among the prose text, no Psalms are included.

5 These also include Psalms 151 and 154-155 (= Syriac Psalms II and III) that were previously only known from translations. For the editio princeps, see James A. Sanders, The Psalms Scroll of Qumran Cave 11 (11QPS ) (DJD 4; Oxford: Clarendon, 1965); Florentino García Martínez, Eibert J. C. Tigchelaar and Adam S. van der Woude, "11QPsb," in Qumran Cave 11, II. 11Q2-18, 11Q20-31 (ed. F. García Martínez, E. J. C. Tigchelaar and A. S. van der Woude; DJD 23; Oxford: Clarendon, 1998), 37-47; Eugene Ulrich, Patrick Skehan and Peter Flint, "4QPs,", in Qumran Cave 4, XI. Psalms to Chronicles (ed. E. Ulrich, P. Skehan and P. Flint; DJD 16; Oxford: Clarendon, 2000), 85-106.

6 For the official DJD edition, see Florentino García Martínez, Eibert J. C. Tigchelaar and Adam S. van der Woude, "11QapocrPsalms," in Qumran Cave 11, II. 11Q2-18, 11Q20-31 (ed. F. García Martínez, E. J. C. Tigchelaar and A. S. van der Woude; DJD 
are all included, as are the apocryphal psalms still only available in Syriac (Psalms 152-153 = Syriac Psalms IV-V). ${ }^{7}$ In addition, the psalms in the collections labeled as 4QNon-Canonical Psalms A+B (4Q3804 Q381) are included because they have pseudepigraphic attributions to different biblical figures such as, e.g., Obadiah (4Q380 frg. 1, 2:8) and Manasseh (4Q381 frg. 33A, 8). ${ }^{8}$ According to their editor, Eileen Schuller, these psalms should be dated roughly to the Persian or Early Hellenistic period, 9 which supports the idea that at least some of these

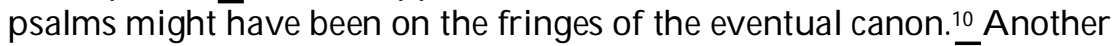
collection that has been included is the Barkhi Nafshi hymns (4Q434438) as they are similar in structure to Psalms 103 and 104.11 It is unclear whether these hymns derive from the Qumran movement or not,12 but as the issue is far from certain the hymns are treated here. Overall, much of the material examined in this article is quite fragmentary which makes it impossible to give an exact number of psalms, but a rough estimate is that there are approximately thirty psalms included in this study.

23; Oxford: Clarendon, 1998), 181-205. After this, modifications to the edition have been suggested by Émile Puech, "Les Psaumes davidiques du rituel d'exorcisme (11Q11)," in Sapiental, Liturgical and Poetical Texts from Qumran: Proceedings of the Third Meeting of the International Organization for Qumran Studies, Oslo 1998. Published in Memory of Maurice Baillet (ed. D. K. Falk, F. García Martínez \& E. M. Schuller; STDJ 35; Leiden: Brill, 2000), 160-81; Mika S. Pajunen, "11QPsAp a , A Communal Ritual Of Exorcism" (paper presented at the fifth annual meeting of the OTSEM network, Lund, Sweden, 22 April 2008).

7 For a study on the Syriac Psalms, see Harry F. van Rooy, Studies on the Syriac Apocryphal Psalms (JSSSup 7; Oxford: Oxford University Press, 1999).

8 For the editio princeps in the DJD series, see Eileen M. Schuller, "4QNon-Canonical Psalms A+B," in Qumran Cave 4, VI. Poetical and Liturgical Texts, part 1 (ed. C. Newsom and E. Schuller; DJD 11; Oxford: Clarendon, 1998), 75-173. For a fuller discussion on many of the themes, see Eileen M. Schuller, Non-Canonical Psalms from Qumran: A Pseudepigraphic Collection (HSS 28; Atlanta: Scholars Press, 1986).

9 Schuller, "4QNon-Canonical," 78.

10 For some of these psalms, the strong Davidic character of the Psalter might have been the eventual reason for their exclusion.

11 For the editio princeps, see Moshe Weinfeld and David Seely, "Barkhi Nafshi," in Qumran Cave 4, XX. Poetical and Liturgical Texts, Part 2 (ed. E. Chazon et al.; DJD 29; Oxford: Clarendon, 1999), 255-334.

12 For arguments on behalf of seeing the text as deriving from the Qumran movement, see, e.g., Weinfeld and Seely, "Barkhi," 258-59. However, the links between Barkhi Nafshi and the texts associated with the movement are not specific enough and more study on these hymns is needed to decide this question. 
The problem of defining "Deuteronomistic" is also a notoriously difficult task that seems to be getting more and more challenging. ${ }^{13}$ There is no large-scale agreement over this, but as, e.g., Moshe Weinfeld has shown, specific Deuteronomistic phraseology is an important criterion in establishing a firmer link with the ideology. ${ }_{-1}^{14}$ Many of the ideas enforced by the Deuteronomists, such as retribution according to deeds, are common motifs in other texts of the Hebrew Bible as well as the Ancient Near East as a whole and without the specific language the exact source these ideas derive from in a specific text cannot be shown with certainty. Nevertheless, it can certainly be noted that several apocryphal psalms implicitly use motifs common to the Deuteronomistic ideology without taking up the particular language (at least on a larger scale). The idea of God testing individuals (בחן), which implies judgment in accordance with deeds, is present, e.g., in the Apostrophe to Zion (4QPsf 8:2-5 =11QPsa 22:12), the Eschatological Hymn (4QPs ${ }^{\mathrm{f}}$ 9:57), Barkhi Nafshi ${ }^{a}$ (4Q434 frg. 1, 1:7) and Non-Canonical Psalms B (4Q381 frgs. 24a, 6; 46a+b, 5-6; 48, 4). God choosing Zion is found, e.g., in the Apostrophe to Zion (4QPs $\left.7: 14-8: 16=11 \mathrm{QPs}^{\mathrm{a}} 22: 1-12\right)$ and Barkhi Nafshia (4Q434 frg. 2, 6-7). The election of David is present in Psalm 151 (11QPsa 28:8-11), 152:4, 153:2 and the choice of Israel from among the nations in 155:21. Some of these ideas most likely derive primarily from Deuteronomistic texts, but the ideas are already at the time of the writing of most of the surveyed compositions so thoroughly embedded in the theological framework of the authors that there is no apparent need to borrow the exact language. 15 Thus, the possible Deuteronomistic influence in the above psalms is more implicit and subtle than in texts also using the actual Deuteronomistic phraseology. On the other hand, language alone is not enough if the text does not have other links

13 The meaning of the term "Deuteronomistic" is discussed, e.g., in Richard J. Coggins, "What Does 'Deuteronomistic' Mean?," in Those Elusive Deuteronomists. The Phenomenon of Pan-Deuteronomism (ed. L. S. Schearing and S. L. McKenzie; JSOTSup 268; Sheffield: Sheffield Academic Press, 1999), 22-35. For Deuteronomistic history and a survey of its past research, see, e.g., Steven L. McKenzie, "Deuteronomistic History," ABD 2:160-68; Thomas C. Römer, The So-Called Deuteronomistic History. A Sociological, Historical and Literary Introduction (London: T\&T Clark, 2005), 13-43.

14 Moshe Weinfeld, Deuteronomy and the Deuteronomic School (Oxford: Clarendon, 1972), $1-3$.

15 Note the theory about Deuteronomistic ideology as a kind of basic theology of the Second Temple period; see, e.g., Timo Veijola, "The Deuteronomistic Roots of Judaism," in Sefer Moshe. The Moshe Weinfeld Jubilee Volume. Studies in the Bible and the Ancient Near East, Qumran, and Post-Biblical Judaism (ed. C. Cohen et al.; Winona Lake: Eisenbrauns, 2004), 459-78. 
with the ideology - isolated words in a context otherwise unrelated to the Deuteronomistic ideology are not sufficient. ${ }^{16}$

Therefore, the task at hand is to search for $\bar{p}$ salms that exhibit particular Deuteronomistic influence by their use of both Deuteronomistic motifs and phraseology. When the above-listed compositions are studied from this perspective it is found that, except for the noted instances implying the ideology without the vocabulary and the isolated words without a larger framework, there are three psalms in this corpus that use Deuteronomistic idioms in a more profound way when they deal with the themes of justice, the choice of Zion and the choice of Israel.

\section{A Solomonic Psalm with a Celestial Trial (11QapocrPs 2:1- 3:13) ${ }^{17}$}

Column 2

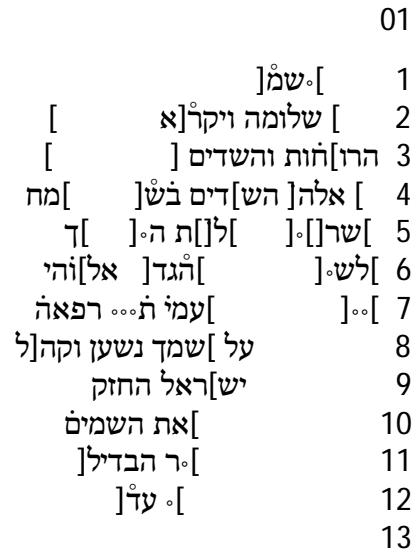

Column 3

$$
\begin{aligned}
& \text { [את הימ] } \\
& \text { ]ארץ מי ע[שה את האותות] } \\
& 1 \\
& 2
\end{aligned}
$$

16 The list of Deuteronomistic phraseology collected by Weinfeld, Deuteronomy, 320-65, rightly focuses almost entirely on idioms and phrases, not individual words.

17 The Hebrew text and the translation are taken from Pajunen, "Communal," 8-10. 


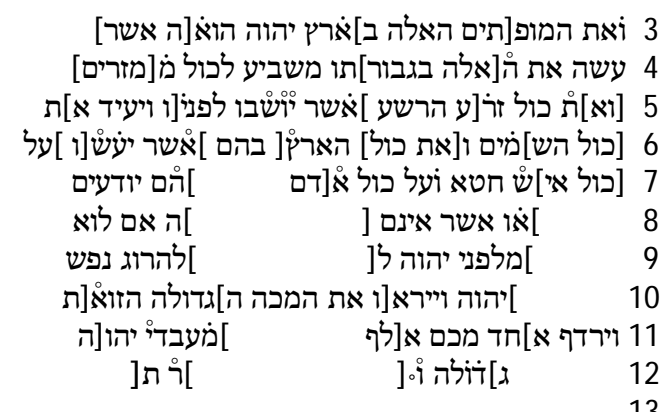

\section{Translation:}

\section{Column 2}

01 --- $1[\ldots] \ldots[\ldots] 2[\ldots]$ Solomon and he will cry for $h[\operatorname{elp} \ldots] 3[\ldots$ spi]rits and demons $[\ldots] 4[\ldots]$ These are [the de]mons ... [...] ... $5[\ldots]$ $\ldots[\ldots] \ldots[\ldots] \ldots[\ldots] \ldots 6[\ldots] \ldots[\ldots] \ldots[\ldots]$ my $[\mathrm{Go}] \mathrm{f} 7[\ldots]$ with me. $\ldots$ a cure $8[\ldots]$ relying [upon] your name and the assem[bly $9[\ldots$ Is]rael. Strengthen $10[\ldots]$ the heavens $11[\ldots] \ldots$ separated $[\ldots] 12[\ldots]$ ... until[...] 13-

\section{Column 3}

01 --- $1[\ldots] \ldots[\ldots] \ldots[\ldots] 2$ to the earth and .... [... ]earth. Who m[ade these miracles] 3 and wond[ers on the] earth? He, YHWH [is the one who] 4 made $t$ [hese through] his [streng]th, who compels the $\mathrm{b}$ [astards] 5 [and] all the see[d of evil ]that have been set before [him], to take an oath. [And he calls ] 6 [all the hea]vens and[ all] the earth [as witnesses against them ]who committ[ed ]upon 7 [all me]n sin and against all pe[ople ...] ... they know $8[\ldots]$... which they do not $[\ldots] \ldots$ if not $9[\ldots]$ from before YHWH ... [...]killing the soul $10[\ldots]$ Yahweh. And [they] will fear tha[t] great [blow.] 11 [And o]ne of you [will put to flight] a tho[usand ...] of the servants of $\mathrm{YHW}[\mathrm{H}] 12$ [... g]reat and $[\ldots] \ldots[\ldots] 13$-...

The first of the psalms is preserved in 11QapocrPs (11Q11), a ritual of exorcism consisting of apocryphal psalms and ending in Psalm $91 .^{18}$

18 Most scholars agree that the manuscript consists of a ritual of exorcism, see, e.g., Émile Puech, "11QPsApa: Un rituel d'exorcismes. Essai de reconstruction," RevQ 14 (1990): 403; Philip S. Alexander, "'Wrestling against Wickedness in High Places': Magic in the Worldview of the Qumran Community," in The Scrolls and the Scriptures. Qumran Fifty Years After (ed. S. E. Porter and C. A. Evans. JSPSup 26. Sheffield: Sheffield Academic Press, 1997), 326-27; Russell C. D. Arnold, The Social Role of Li- 
This is the second of the at least five preserved psalms in the scroll and the mention of Solomon's name (col. 2:2) means that this psalm is probably ascribed to him.19 ${ }^{19}$ The psalm is directed against many categories of evil spirits either to banish them from a person or to provide protection from their attacks. The first extant parts of the psalm are a list of demons (2:4-5) followed by a plea to God for a cure and support (2:5-9). The next lines (2:10-3:2) might have something to do with God and the creation but the isolated words are not enough to be sure. The bestpreserved section of the psalm centers on a celestial trial against the evil spirits (3:2-10) and it is here that the Deuteronomistic influence is found.

First, the sovereignty of God as the judge is established by recounting his former deeds. Unlike the Hebrew Bible where the Deuteronomistic word pair אתות ומופתים is used to refer to the deeds of God in Egypt (e.g., Deut 4:34, 6:22), it is most likely referring here to the works of creation. Creation is used to show why God is infinitely more powerful than any of the spirits he rules over. This picture of God the Creator and almighty heavenly judge contains the notion of him as the only real God, which is a basic Deuteronomistic tenet. After this section the accused spirits are set before God to be tried (3:4-5).20 Then heaven and earth are called as witnesses against them (3:5-6). This notion of heaven and earth as witnesses derives from Deuteronomy (cf. Deut 30:19, 31:28) and there are two ways of understanding its use in this psalm: either it tells something about the relationship between God and the spirits, i.e., it is meant to encourage a comparison with Israel's covenantal relationship with God in Deuteronomy, or it is taken up just because of the cosmic dimension of the trial. No firm answer can be given but it is an intriguing possibility that a kind of vassal relationship might have been seen to exist between God and the spirits and this was breached by the actions of some of the spirits (cf. the Book of Watchers). The charges leveled against the evil spirits (3:6-8) concern their actions against humankind. It is worth noting that the sinful deeds of the spi-

turgy in the Religion of the Qumran Community (STDJ 60; Leiden: Brill, 2006), 167; Mika S. Pajunen, "The Function of $11 \mathrm{QPsAp}^{\mathrm{a}}$ as a Ritual," in Text and Ritual. Papers presented at the symposium Text and Ritual (ed. A. K. Gudme; Copenhagen: University of Copenhagen, 2009), 50-60. The version of Psalm 91 preserved in 11QapocrPs has a number of differences in comparison to the MT Ps 91. The reason behind these variant readings has been analyzed in Mika S. Pajunen, "Qumranic Psalm 91: A Structural Analysis," in Scripture in Transition: Essays on Septuagint, Hebrew Bible, and Dead Sea Scrolls in Honour of Raija Sollamo (ed. A. Voitila and J. Jokiranta; JSJSup 126; Leiden: Brill, 2008), 591-605.

19 For Solomon as a composer of exorcisms see, e.g., Josephus, Ant. 8.45-49.

20 Cf. 1 Kgs 21:9-10. 
rits are the reason for the trial, namely, they have transgressed a boundary set for them. As is well known, retribution according to deeds is part of the Deuteronomistic ideology. Next the verdict for the sins of the spirits is given (3:9-10), but unfortunately only the last sentence of this verdict is even relatively well preserved on the manuscript. The word pair מכה גדולה is most often used in connection with military victory (cf. Josh 10:10, 10:20; Judg 11:33, 15:8) but one must also bear in mind the prominent use of the noun מכה in the covenant curses of Deut 28:59-61.

The last line that can be interpreted with any amount of certainty (3:11) switches the address to the audience that is present at the recitation and declares their power as the servants of God over the evil spirits. The first of the most likely two parallel colons in line 11 reinforces the notion that the composer of the psalm was thinking about military traditions also in line 10 as the colon seems to be referring to Josh 23:10. Even though the address changes, when the background traditions are properly understood then this and the preceding colon make up a continuum. The first colon establishes that God will wage war against the spirits because of their evil deeds and the second that the audience has the power to chase away a thousand demons. This is exactly the notion given in Josh 23:10 which is part of a Deuteronomistic military oration: that when God wages war on behalf of his chosen ones then they are able to chase away a thousand enemies. This promise of God only applies to those who act in accordance with his will and it derives from the covenant blessings in Deut 28:7 (cf. Lev 26:6-8). It is likely that the psalm ends soon after this because the sentence on the evil spirits has been passed and the power of the audience and the speaker over the demons has been established.

Thus, various strands of Deuteronomistic ideology were employed by the author of the psalm, some implicitly and others with Deuteronomistic idioms. However, it is clear that the way the author uses the phraseology and concepts is in some of the instances quite different from the usage of the same phrases and concepts in the Hebrew Bible. He uses the traditional formulations and draws upon the ideological notions but transfers them to a new context. He refers to the signs and wonders God has done in the past as a sign of his power just as the Deuteronomists did, but where they used it in connection with the deliverance of Israel from Egypt the author of this psalm applies it to the creation. The wonders in Egypt were meaningful for Israel as a national entity, but in this psalm the author appears to be concerned with the power of God over the evil spirits, and the signs in Egypt are not as relevant in that respect as the acts of creation. Similarly the con- 
cept of a trial where God judges according to deeds and calls heaven and earth as witnesses is taken from the model established in Deuteronomy, but in this psalm the trial is applied to the evil spirits instead of Israel. Contrary to these instances, when the psalmist talks about the verdict of the evil spirits and the power given to the audience, again by using Deuteronomistic sources, he does not need to change the basic meaning of the traditions because they fit the situation without a need for modification. In the psalmist's interpretation his sources say that, as followers of the commandments of God, the blessings of Deuteronomy are applicable to the audience and therefore God will fight for them and they are able to chase away a thousand demons as promised. While the psalm is difficult to date, the way the sources are used and the prominent role the spirits have in the composition (especially the specialized list in 2:3-4) suggest that it should be dated at the earliest to the second century B.C.E. and probably to the latter half of it.

\section{Zion the City Chosen by YHWH (4Q380 frg. 1, 1:1-2:6) ${ }^{21}$}

\section{Column 1}

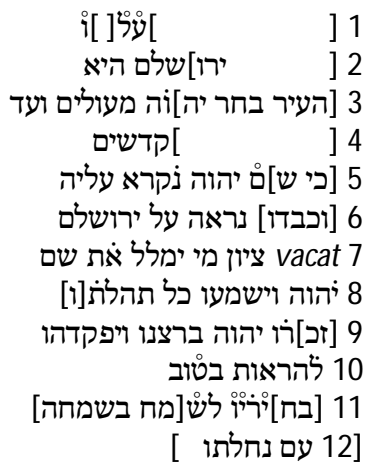

Column 2

$$
\begin{aligned}
& 1
\end{aligned}
$$

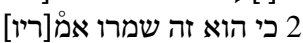

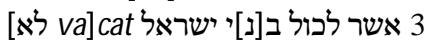

21 The Hebrew text and the translation follow Mika S. Pajunen, "The Textual Connection between 4Q380 Fragment 1 and Psalm 106," in Proceedings of the DSS and the Hebrew Bible section in Rome 2009 (ed. A. Lange et al.; SBL series, forthcoming). 


\section{Translation:}

\section{Column 1}

$1[\ldots] \ldots[\ldots] \ldots 2[\ldots$ Jeru]salem, that is 3 [the city $\mathrm{YH}] \mathrm{WH}$ [chose] forever and ever $4[\ldots]$ holy ones 5 [for the na]me of YHWH is invoked upon it 6 [and his glory] is seen upon Jerusalem. 7 vacat

O Zion! Who can utter the name of $8 \mathrm{YHWH}$ and who are the ones to declare all [his] praise? 9 YHWH [remem]bered him in his favor. And visited him 10 to let him experience the prosperity of 11 his [chos]en ones, to make him [rejoice in the gladness (12) of the people of his inheritance]

\section{Column 2}

1 (what) [can] he/it do for you (pl.)? Their fortune is God 2 for he is the one [whose] wo[rds] they kept 3 which are for all the ch[ild]ren of Israel. vacat

4 Your (sg.) hand will [not] save you (sg.) for strength is for the [one who] 5 does goo[d] and the ones who hate the wicked. How[ long] 6 will you (pl.) delight to do evil lest puni[shment] is multiplied for you (sg.)? 7 vacat (end of psalm)

The second psalm belongs to the collection 4QNon-Canonical Psalms A (4Q380) and is the only one of the psalms in 4 Q380 to be even moderately well preserved. It is probably the oldest of the three psalms under investigation as it has already been used as a source by the compiler of MT Psalm 106.22 It is part of a psalm collection that was possibly made up of psalms ascribed to different prophets. ${ }^{23}$ The first extant part

22 There is a textual connection between 4Q380 frg. 1, 1:7-11 and MT Psalm 106:2-5. Schuller, Non-Canonical, 32-34, 257, claims that the 4Q380 psalm is using Psalm 106, but George Brooke, "Psalms 105 and 106 at Qumran," RevQ 54 (1989): 267-92, suggests that the influence goes the other way and a thorough treatment of the question in Pajunen, "Textual," reinforces Brooke's view.

23 Cf. Eileen M. Schuller, "Qumran Pseudepigraphic Psalms (4Q380 and 4Q381)," in The Dead Sea Scrolls: Hebrew, Aramaic and Greek Texts with English Translations. Vol. 4A, Pseudepigraphic and Non-Masoretic Psalms and Prayers (ed. J. H. Charlesworth and H. W. L. Rietz; Tübingen: J. C. B. Mohr, 1997), 1-2; Pajunen, “Textual.” 
of the psalm deals with the Deuteronomistic theme of God choosing Jerusalem as the dwelling place for his name (1:2-6). Lines 4 and 5 are especially noteworthy for on these parallel colons both the name (שם) and the glory (כבד) of God are used in connection with Jerusalem. The first phrase is a common Deuteronomistic idiom (cf. $1 \mathrm{Kgs}$ 8:43) and the second seems dependant on Isaiah 60:2.

The next stanza (the break indicated by a vacat) is the one with a connection to Psalm 106:2-5 and it deals with the joy of the ones who are able to take part in the Jerusalem cult. It starts with a question (1:78) that is answered in the next colons (1:9-12). ${ }^{24}$ Here the most intriguing question for this investigation is about who are referred to as the chosen ones. The expressions "his chosen ones" and "the people of his inheritance" are parallel and therefore refer to the same group. עם נחלתה is a Deuteronomistic idiom used of the nation of Israel (cf. Deut 4:20; 9:26, 29) and בחר is also frequently used of Israel (cf. Deut 4:37, 10:15, 14:2). However, especially in light of the second column it seems that not all who belong to the people of Israel are automatically included in this elect group. The second column compares the actions of two groups belonging to the people of Israel. The ones who act in accordance with the words of God are surely included under the group terms applied here, but the ones who do not comply most likely are not. But as the aim of the psalmist seems to be to change the behavior of these people, it follows that by complying they will be able to enter among the chosen ones who make up the people of God's inheritance. After this the text breaks off until the beginning of the second column.

In the second column, where the ending of the psalm is preserved, more words and motifs common to the Deuteronomistic ideology are found. The actions of the pious are described as observance of God's words (2:2) and doing good (2:5). These are the same verbs (שמר and עשה) used frequently, e.g., in the Deuteronomy (cf. 26:16; 28:1, 15) of the obligation to follow the laws. From the polemics used it is easy to deduce that some of the people are not following these commandments that are meant for all Israelites (2:3-4) but are taking the law into their own hands. The continuing of these actions will evoke punishment from God (2:6). Particularly interesting is that the psalmist basically lays out the choice of Deuteronomy 28 for the disobedient people, i.e., observe the commandments and prosper among the chosen people or

24 The question is similar to the one used in Psalm 15:1, i.e., both answer the question by giving qualifications of the person (cf. Ps 106:3) who will be able to answer the question positively (although most of the actual qualifications, e.g., observance of the law, are only implicitly preserved in the extant text of the 4 Q380 psalm) and both deal with the cult. For the act of declaring the name and praises cf. Ps 102:22. 
continue to do evil and be punished. The rewards of the proper choice are well described in the first column (1:9-12) and it might well be that the possible punishment was envisioned in the lost parts of the psalm. It is clearly the expectation of the psalmist that the disobedient people will be punished for their deeds but the judgment is restricted to them, in other words, their actions will not draw a calamity upon the whole nation, only themselves. The chosen ones will instead enjoy the rewards of their actions while observing the punishment of the wicked.

As has been discovered, this psalm uses many different Deuteronomistic motifs and also some of the specific phraseology. Of the three psalms discussed in this article this one is closest to the time when the Deuteronomistic ideology was formulated and henceforth incorporated into literature. This can be seen by observing the use of the motifs. They are still being applied in much the same sense as in the texts of the Hebrew Bible and in a similar situation: the author is concerned about the observance of the commandments among the people of Israel. He uses the basic words and idioms of the Deuteronomistic ideology and applies them to the specific situation without major reinterpretation, i.e., he actualizes some of the aims of the original ideology in his own setting by glorifying Zion, exulting in the prosperity of those who observe the law and admonishing the disobedient ones about the consequences of their choices.

\section{Israel the Chosen Nation (4Q381 frgs. 77 and 69)25}

\section{Fragment 77}

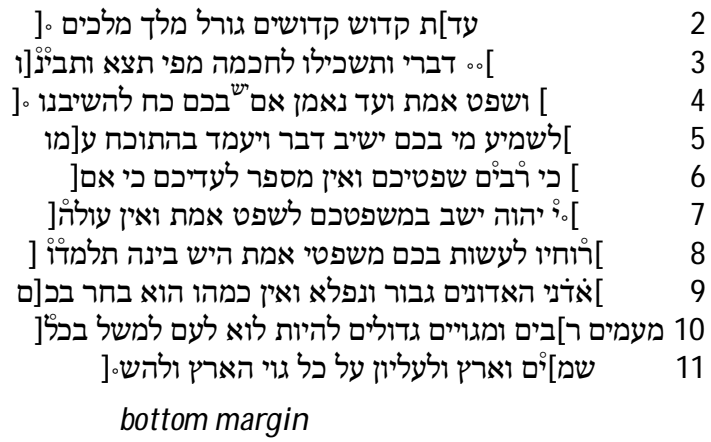

25 The Hebrew text and the translation are taken from Schuller, "4QNon-Canonical," $149-50,155-57$. 
Fragment 69

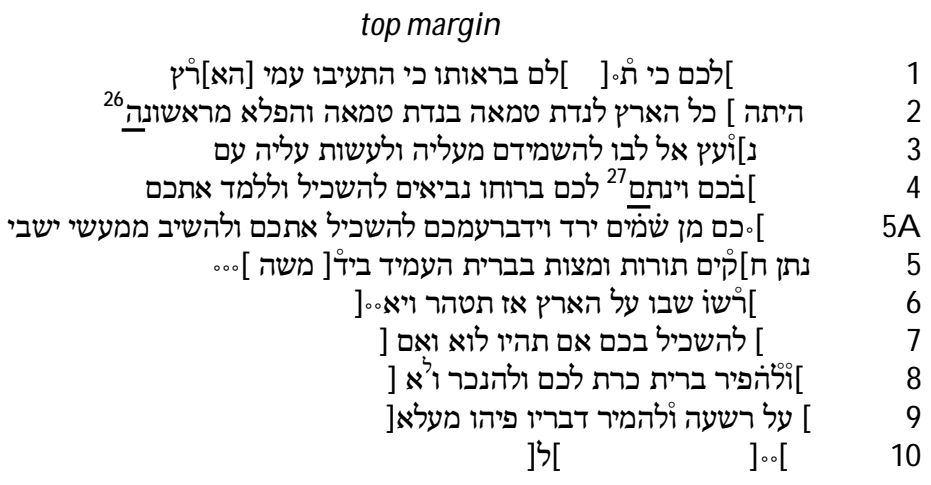

\section{Translation:}

Frg. 77

2 congrega]tion of the Holy of Holy Ones, company of the King of Kings ...[ ] 3 [ ]... my words, and you will pay attention to the wisdom (that) goes forth from my mouth, and you will understand[ ] 4 [ ] and a true judge and a faithful witness. Do you have strength to answer him ...[ ] 5 [ ]... to proclaim. Who among you will reply, and stand in dispute wi[th him ] 6 [ ] for many are those who judge you, and there is no number to those who witness against you. But[ ] 7 [ ]... YHWH sits in judgment with you to judge truly, and there is no injustice[ ] 8 [ ]his spirits, rendering you true judgments. Is there understanding (which) you may learn [ ] 9 [ ]Lord of Lords, mighty and

26 The last letter of the penultimate word was first written by the scribe as a clear $\lambda$ but he later added another stroke to apparently change the letter into an $\mathrm{k}$. The stroke is deliberate and not an accidental drop of ink so $\mathrm{s}$ should be read. The reason for the later corrected mistake might be related to the meaning of the word. If one reads the word as coming from the root פלא, as Schuller, Non-Canonical, 204-05, does, then it is very hard to make sense of the passage and there is no apparent reason for the scribe's mistake. However, if one takes into account that $ה$ is replaced by $\boldsymbol{N}$ eight times in this manuscript, (for a list see Schuller, Non-Canonical, 64) it is possible that the root meant by the scribe was actually פלה "to separate". The meaning of the root is close to פלג "to divide" so the mistake of the scribe could relate to mixing up the two roots.

27 As noted by Schuller, Non-Canonical, 205, the unusual form is probably a consequence of metathesis (וינתם for ויתנם). 
marvelous, and there is no one like him. He chose y[ou 10 from ma]ny [peoples] and from great nations to be his people, to rule all[ ] 11 [ hea]ven and earth, and as most high over every nation of the earth, and ...[ ]

\section{Frg. 69}

1 [ ]... because ...[ ]... When he saw that the peoples of [the la]nd acted abominably 2 [ ]all the land [became] total unclean defilement. And he set apart from the former ${ }^{28} 3$ [ he to]ok counsel with himself to destroy them from upon it, and to make upon it a people 4 [ ]... and to give them to you by his spirit, prophets to instruct and to teach you 5a [ ]... from heaven he (God) came down, and he spoke with you to instruct you, and to turn (you) away from the deeds of the inhabitants of 5 [ He gave la]ws, instructions and commandments by the covenant he established through[ Moses ]... 6 [ ]take possession, dwell upon the land; then it will be purified, and ...[ ] 7 [ ] to consider among yourselves, if you will be his, or if [ ] 8 [ ] ] and to break the covenant he cut with you, and to act as strangers, and not [ ] 9 [ ] against wickedness, and to change the words of his mouth .... [ ] 10 [ ]...[ ]...[ ]

The third psalm is preserved in 4QNon-Canonical Psalms B (4Q381). The manuscript consists of 109 fragments that preserve text from at least eight separate psalms. Many of these seem to be individual praises and penitential prayers ascribed to different kings, e.g., Manasseh (frg. $33,8)$, but other themes such as the creation (frgs. 1, 14) are also present. Many of these psalms exhibit the influence of Deuteronomistic ideology, e.g., in the assessment of the kings and expecting direct divine retribution for sins, but these references are only implicit. However, contrary to the other psalms in this manuscript, this particular psalm shows marked and quite explicit Deuteronomistic influence. The psalm deals with the history of Israel as the chosen nation and text from the psalm is preserved on two of the larger fragments (frgs. 69 and 77). The fragments make up a continuous sequence with fragment 77 having text from the last eleven lines of a column (the psalm starts on line 2) and fragment 69 from the first ten lines of the next column. ${ }^{29}$

28 Schuller, "4QNon-Canonical," 150, translates the last part of the line: "And marvelously from the first." For the reason behind the different translation, see the footnote for line 2 of the Hebrew text.

29 Bilhah Nitzan, "Post-Biblical Rib Pattern Admonitions in 4Q302/303a and 4Q381 69, 76-77," in Biblical Perspectives: Early Use E Interpretation of the Bible in Light of the Dead Sea Scrolls. Proceedings of the First International Symposium of the Orion Center for the 
Eileen Schuller has already observed that the psalm employs "vocabulary and stylistic devices typical of the Deuteronomistic school," the psalm does indeed provide an interesting example of the use of Deuteronomistic language and ideas.

The psalm starts with a wisdom section (frg. 77, 2-8) that gives the interpretive frame for the following parts of the psalm that deal with the history of Israel. The author's overall aim appears to be to show that God has acted correctly when he has judged Israel. ${ }^{31}$ With the aid of questions and other wisdom forms, he first discusses God as judge and witness in comparison to humans. He begins by addressing the audience and then admonishing them to take heed of his words (lines $2-3)$. Then the psalmist relates what the audience should understand by listening to his words (first part of line 4), namely, that God's justice is reliable and just. This is the central interpretive frame given here for the entire psalm but it is also the subject of the whole introductory part. ${ }^{32}$ The second part of line 4 opens a list of rhetorical questions that also continues on the next line. All the verbs used in these questions also have judicial connotations and the questions focus on justice, specifically, on whether human beings are able to stand up to God (cf. 4 Q185 frg. 1, 1), challenge the truth of his verdicts, etc. The evidently negative answer to these questions is given in line 6, which apparently speaks about there being multiple people ready to judge and give testimony concerning the audience, that is to say, there are numerous would-be judges and (most likely controversial) witnesses. The continuation starting with כי אם probably explains the problem inherent in this notion of justice within human hands and thus lays out the groundwork for the contrast between human and divine justice. In contrast to humans, $\mathrm{YHWH}$ as the sole judge is reliable and just (line 7).

Study of the Dead Sea Scrolls and Associated Literature, 12-14 May 1996 (ed. M. E. Stone and E. G. Chazon; STDJ 28; Leiden: Brill, 1998), 171, treats the fragments as parts of separate psalms. However, Schuller, Non-Canonical, 225-26, suggests that the fragments are from the same psalm and gives stylistic, linguistic and form-critical arguments that make the connection between the fragments more than plausible. Furthermore, the preliminary material reconstruction of the manuscript by Hartmut Stegemann (published in Schuller, Non-Canonical, 267-83) supports this sequence and observation of the original manuscript shows that the appearance of the fragments is very similar and there is no material reason that would speak against the sequence.

30 Schuller, Non-Canonical, 225.

31 The viewpoint of the author seems to be similar to that expressed in Neh 9:33.

32 As Schuller, Non-Canonical, 221, points out, the wording recalls especially Jer 42:5. Note also Psalm 89:38 where Timo Veijola, "The Witness in the Clouds: Ps 89:38," JBL 107 (1988): 413-17, has conclusively shown the faithful witness to be God. 
It has to be noted that this is the only surviving use of the tetragrammaton in this psalm and it serves to give special emphasis to this statement, i.e., it is none other than YHWH who will judge his people (cf. Deut 32). The wisdom section draws to a close by including God's spirits as mediators of divine justice (for a similar notion see, e.g., 4Q185 frg. 1, 1:8-9) and assuring the audience that there surely are insights for them to learn from this. The phraseology in this section is not specifically Deuteronomistic, but it is nevertheless worth noting that the theme of God judging Israel is probably based on Deuteronomy as the thematic links with, e.g., Deut 32 show.

As a transitional device between the wisdom section and the next part that deals with Israel as the chosen nation the psalmist has used an exclamation of God's magnificence with a partly Deuteronomistic wording. For the first part of the exclamation the psalmist may have been thinking specifically of Deut 10:17 as both גבר אדני האדנים occur there and that verse also speaks about God being an unbiased and incorruptible judge. The exclamation ends with the basic Deuteronomistic creed that there is no other God like YHWH.

After establishing God as the only true and faithful judge the text moves to the choosing of Israel and the blessings inherent in the choosing (frgs. 77, 9-11; 69, 1-3). Israel is God's chosen people and hence it is the highest among nations and it is accorded the mandate to rule (frg. 77, 9-11). Almost all of these phrases are standard Deuteronomistic בחר (of Israel) cf. Deut 4:37, 7:6, 10 et al., for גויים גדולים cf. Deut 4:38, 9:1, 11:23 et al., and for להעליות לו לעם cf. Deut 4:20, 7:6, 14:2 et al. The phrase גוי הארץ ולעליון על כל seems to be a direct quotation from Deut 28:1 (or less directly of 26:19). Another blessing related to this choice is the giving of the land to Israel and this is what the beginning of fragment 69 (lines 1-3) deals with. First the psalmist gives a reason for the removal of the former inhabitants from the land. Their main faults are abominable deeds that cause impurity to the land. Because of these deeds God plans to exterminate them and bring his chosen nation there instead. In the first lines the author uses Ezra 9:11 as noted already by Eileen Schuller. ${ }^{33}$ The wording quite clearly comes from that passage as the ideas in Ezra 9:11 are quite distinctive in the Hebrew Bible, as pointed out by Juha Pakkala. ${ }^{34}$ There are no explicit Deuteronomistic idioms in this passage, but reconstructing the Deuteronomistic expression עדש 4 [קדש "holy people" (cf. Deut 7:6, 14:2, 21, 26, etc.) is

33 Schuller, Non-Canonical, 204.

34 Juha Pakkala, Ezra the Scribe. The Development of Ezra 7-10 and Nehemia 8 (BZAW 347; Berlin: Walter de Gruyter, 2004), 115. 
quite plausible as it would lay out a sharp contrast with the abominable deeds of the former inhabitants just mentioned.

The next major part of the psalm deals with what God expects from his chosen people in return (frg. 69, 4-6). It details the obligations of the Israelites given by God through various mediators. The prophets are mentioned first as given to Israel to instruct and teach, i.e., to tell how to live in accordance with the will of God. ${ }^{35}$ Alex Jassen has shown by analysis of the biblical basis of this phrase that the prophets are not seen as transmitting the actual Torah but as instructors who make the law intelligible and applicable in different settings. ${ }^{36}$ After the giving of the prophets, the Sinai events and the making of the covenant are presented (lines 5A-5). It is important to note that the text gives as the central reason (or one of them) behind the Sinai theophany that God wanted to turn Israel away from the works of the inhabitants of the land. This is hardly chronological but does reveal something about the concerns of the author of the psalm. ${ }_{-1}^{37}$ After the Sinai events, direct commands are given to take possession of the land and dwell in it. This will then purify the land (presumably on the condition that the instructions given by God through Moses and the prophets are kept) from the uncleanness caused by the previous inhabitants. The psalmist has used Neh 9 as a source when writing the text in lines 4-5.38 The covenant, instructions and commandments, etc., are of course also common

35 Schuller, Non-Canonical, 206, finds it slightly problematic that the prophets are mentioned before the Sinai events, but it need not be seen so. First of all, the divine plan to give the land to Israel was already discussed so the structure is not motivated by strict chronology as is also seen in line $5 \mathrm{~A}$. Second, as Schuller herself mentions, prophets in general are in some texts of the Hebrew Bible already assigned to the wilderness period (e.g., Jer 7:25, Amos 2:11). Third, in this particular case the sequence might come from the author still having in mind the already mentioned Ezra 9:11 where the words about the coming conquest of the land are put into the mouths of prophets, i.e., to the period of wandering in the desert. Cf. Alex P. Jassen, P. Mediating the Divine. Prophecy and Revelation in the Dead Sea Scrolls and Second Temple Judaism (STDJ 68; Leiden: Brill, 2007), 54.

36 Jassen, Mediating, 55-57.

37 The need to act differently from other nations and their practices is emphasized by the author and most likely reflects the situation of his day and is part of the message he wants to impart to his intended audience. Nitzan, "Post-Biblical," 173-74, has noted the same tendency, but goes perhaps a bit far in claiming that we could pinpoint the situation that this refers to, specifically, to relationships between the Jews and Samaritans. It is better to view it as a general commandment to stay away from foreigners, their practices and influence be they the Samaritan people, Hellenistic thought, etc.

38 For a comprehensive list of parallel language and imagery with Neh 9 (especially vv. 13-14, 20), see Schuller, Non-Canonical, 209-10. 
themes in Deuteronomistic literature as is taking possession of the land (line 6).

The final extant part of the psalm presents a covenantal choice to remain the privileged people and act according to the preceding commands or to act as foreigners and break the covenant (frg. 69, 7-9). The choice is basically the same as in Deut 28: those who follow the law will be blessed but those who do not will face the curses. From the negative tone of the last lines it can be guessed that the punishments and their subsequent execution might have been described in the following sections.

The basic pattern of the psalm has elements common with the covenant lawsuit pattern (ריב).39 Bilhah Nitzan has, e.g., drawn attention to the justification of God as judge often preceding an account of Israel's history in texts of the Hebrew Bible (cf. Deut 32:4).40 It is important to note that the author is familiar even with many quite late texts and is able to use them in concert to drive his point home. For the choosing of Israel, the terms used for the nation, etc. he uses Deuteronomistic phraseology and ideas, but for his more specific concerns he uses later sources that exhibit similar notions (Ezra 9:11, Neh 9, etc.). The psalmist uses the Deuteronomistic idioms in the traditional way they are used in the Hebrew Bible. The theme he is writing on has influenced the choice of language and it is illuminating to see how he is able to employ the Deuteronomistic phraseology as a stylistic device. The use of late sources like Neh $9^{41}$ and some of the vocabulary indicate that the psalm is quite late. ${ }^{42}$ Most likely it was written around the middle of the $2^{\text {nd }}$ century B.C.E.

\section{Conclusions}

In the analysis of these psalms, three distinct ways of applying Deuteronomistic ideology and phrases were discovered. The oldest of these, exhibited by the $4 \mathrm{Q} 380$ psalm, seems to be the use of the Deuterono-

39 Schuller, Non-Canonical, 225-26. She also rightly points out the differences between the psalm and the pattern and that many parts belonging to it are missing in 4Q381.

40 Nitzan, "Post-Biblical," 163-64.

41 Pakkala, Ezra, 180-84, 210, among others has convincingly argued that Neh 9 is one of the latest parts of that book if not the whole Hebrew Bible (with some exceptions like Daniel).

42 E.g., Schuller, Non-Canonical, 221, has observed that the expression מלך מלכים (frg. 77, 2) is not used of God in the Hebrew Bible, but becomes frequent from the second century B.C.E. onwards. 
mistic concepts as parts of a polemic. Unlike the other two texts, which apparently come from settings where the basic tenets have already been approved, this text is still arguing the points and one gets the sense that here we are dealing with an ideology that is still striving for hegemony by arguing against people not yet committed to its tenets. In a short space the author describes surprisingly many different facets of the Deuteronomistic ideology, e.g., the choice of Zion (1:2-6), the chosen people and their prosperity $(1: 9-11,2: 1)$, retribution for sinful deeds (2:6) and the importance of observing the commandments (2:2-5). But even though the gap in time between the author of this text and the Deuteronomists is much smaller than with the other two psalms investigated here, some modifications have already occurred like the change of viewpoint from a nationwide perspective to the elect/righteous within the nation.

The other psalms are probably chronologically quite close to each other and give two different ways in which the much earlier Deuteronomistic tradition was used at this point in time. The author of the 4 Q381 psalm uses the ideology and vocabulary most of all as a stylistic device when discussing Israel's past. The phraseology aids in creating the setting of the psalm and is an easy way to evoke links to the previous writings in the minds of the audience. The author uses the past as a means to an end, i.e., the audience is meant to identify themselves as heirs to the blessings and curses of the covenant (Deut 28) and to make the correct choices in the future by learning from the mistakes of their forefathers. Thus, the author actualizes the covenantal choice by employing the familiar language and the same basic choice between blessings and curses, but tying it strongly together with his/his group's special concern about foreign practices.

The author of the psalm in 11QapocrPs uses a different strategy when employing parts of the Deuteronomistic ideology. He transfers the familiar terminology (e.g., אתות ומופתים) and ideas into a new setting by partly redefining them. Their use is still similar enough to how they were typically used in the past so as not to directly contradict the previous function, but still distinctly different from it. It is a reapplication/reinterpretation of the concepts in a setting where the traditional formulations would not work per se.

Thus, all three authors are capable of discerning and using different parts of the Deuteronomistic traditions as sources for their compositions. Combining their explicit use of the motifs with the possible implicit influence found in many other apocryphal psalms gives some idea of how deeply embedded the Deuteronomistic ideology was in the circles responsible for these compositions. 


\section{Bibliography}

Alexander, Philip S. “'Wrestling against Wickedness in High Places': Magic in the Worldview of the Qumran Community." Pages 318-37 in The Scrolls and the Scriptures. Qumran Fifty Years After. Edited by S. E. Porter and C. A. Evans. Journal for the Study of the Pseudepigrapha Supplement Series 26. Sheffield: Sheffield Academic Press, 1997.

Arnold, Russell C. D. The Social Role of Liturgy in the Religion of the Qumran Community. Studies on the Texts of the Desert of Judah 60. Leiden: Brill, 2006.

Brooke, George J. “Psalms 105 and 106 at Qumran.” Revue de Qumran 54 (1989): 267-292.

Coggins, Richard J. "What Does 'Deuteronomistic' Mean?" Pages 22-35 in Those Elusive Deuteronomists. The Phenomenon of Pan-Deuteronomism. Edited by L. S. Schearing and S. L. McKenzie. Supplements to the Journal for the Study of the Old Testament 268. Sheffield: Sheffield Academic Press, 1999.

García Martínez, Florentino, Eibert J. C. Tigchelaar and Adam S. van der Woude. "11QPs'." Pages 37-47 in Qumran Cave 11, II. 11Q2-18, 11Q20-31. DJD 23. Oxford: Clarendon, 1998.

—. "11Qapocryphal Psalms." Pages 181-205 in Qumran Cave 11, II. 11Q2-18, 11Q20-31. DJD 23. Oxford: Clarendon Press, 1998.

Jassen, Alex P. Mediating the Divine. Prophecy and Revelation in the Dead Sea Scrolls and Second Temple Judaism. Studies on the Texts of the Desert of Judah 68. Leiden: Brill, 2007.

Josephus. Translated by H. St. J. Thackeray et al. 10 vols. Loeb Classical Library. Cambridge: Harvard University Press, 1926-1965.

McKenzie, Steven L. "Deuteronomistic History." Pages 160-168 in vol. 2 of The Anchor Bible Dictionary. Edited by D. N. Freedman. 6 vols. New York: Doubleday, 1992.

Nasuti, Harry P. Tradition History and the Psalms of Asaph. Society of Biblical Literature Dissertation Series 88. Atlanta: Scholars Press, 1988.

Nitzan, Bilhah. "Post-Biblical Rib Pattern Admonitions in 4Q302/303a and 4Q381 69, 76-77." Pages 159-174 in Biblical Perspectives: Early Use E Interpretation of the Bible in Light of the Dead Sea Scrolls. Proceedings of the First International Symposium of the Orion Center for the Study of the Dead Sea Scrolls and Associated Literature, 12-14 May 1996. Edited by M. E. Stone and E. G. Chazon. Studies on the Texts of the Desert of Judah 28. Leiden: Brill, 1998.

Pajunen, Mika S. "Qumranic Psalm 91: A Structural Analysis." Pages 591-605 in Scripture in Transition: Essays on Septuagint, Hebrew Bible, and Dead Sea Scrolls in Honour of Raija Sollamo. Edited by A. Voitila and J. Jokiranta. Supplements to the Journal for the Study of Judaism 126. Leiden: Brill, 2008.

—. "11QPsApa , A Communal Ritual Of Exorcism." Paper presented at the fifth annual meeting of the OTSEM network. Lund, Sweden, 22 April 2008.

-. "The Function of 11QPsApa as a Ritual." Pages 50-60 in Text and Ritual. Papers presented at the symposium Text and Ritual. Edited by A. K. Gudme. Copenhagen: University of Copenhagen, 2009. 
-. "The Textual Connection between 4Q380 Fragment 1 and Psalm 106," in Proceedings of the DSS and the Hebrew Bible section in Rome 2009. Edited by A. Lange, K. De Troyer \& S. Tzoref. Society of Biblical Literature monograph series, 2011, forthcoming.

Pakkala, Juha. Ezra the Scribe. The Development of Ezra 7-10 and Nehemia 8. Beihefte zur Zeitschrift für die alttestamentliche Wissenschaft 347. Berlin: Walter de Gruyter, 2004.

Puech, Émile. "11QPsApa: Un rituel d'exorcismes. Essai de reconstruction." Revue de Qumran 14 (1990): 377-408.

—. "Les Psaumes davidiques du rituel d'exorcisme (11Q11)." Pages 160-81 in Sapiental, Liturgical and Poetical Texts from Qumran: Proceedings of the Third Meeting of the International Organization for Qumran Studies, Oslo 1998. Published in Memory of Maurice Baillet. Edited by D. K. Falk, F. García Martínez and E. M. Schuller. Studies on the Texts of the Desert of Judah 35. Leiden: Brill, 2000.

Römer, Thomas C. The So-Called Deuteronomistic History. A Sociological, Historical and Literary Introduction. London: T\&T Clark, 2005.

Rooy, Harry F. van. Studies on the Syriac Apocryphal Psalms. Supplement to the Journal of Semitic Studies 7. Oxford: Oxford University Press, 1999.

Sanders, James A. The Psalms Scroll of Qumran Cave $11\left(11 Q P s^{a}\right)$. Discoveries in the Judaean Desert of Jordan IV. Oxford: Clarendon, 1965.

Schuller, Eileen M. Non-Canonical Psalms from Qumran. A Pseudepigraphic Collection. Harvard Semitic Studies 28. Atlanta: Scholars Press, 1986.

-. "Qumran Pseudepigraphic Psalms (4Q380 and 4Q381)," Pages 1-39 in The Dead Sea Scrolls: Hebrew, Aramaic and Greek Texts with English Translations. Vol. 4A, Pseudepigraphic and Non-Masoretic Psalms and Prayers. Edited by J. H. Charlesworth and H. W. L. Rietz. Tübingen: J. C. B. Mohr, 1997.

—. "4QNon-Canonical Psalms A+B" Pages 75-173 in Qumran Cave 4. VI Poetical and Liturgical Texts, part 1. Edited by C. Newsom and E. Schuller. DJD 11. Oxford: Clarendon, 1998.

Tanzer, Sarah. The Sages at Qumran: Wisdom in the Dead Sea Scrolls. Ph.D. diss., University of Harvard, 1987.

Ulrich, Eugene, Patrick Skehan and Peter Flint. "4QPsf." Pages 85-106 in Qumran Cave 4, XI. Psalms to Chronicles. Discoveries in the Judaean Desert XVI. Edited by E. Ulrich et al. Oxford: Clarendon, 2000.

Veijola, Timo. Verheissung in der Krise: Studien zur Literatur und Theologie der Exilszeit anhand des 89. Psalms. Annales Academiae Scientiarum Fennicae B 220. Helsinki: Suomalainen Tiedeakatemia, 1982.

—. "The Witness in the Clouds: Ps 89:38." Journal of Biblical Literature 107 (1988): 413-417.

—. "The Deuteronomistic Roots of Judaism." Pages 459-478 in Sefer Moshe. The Moshe Weinfeld Jubilee Volume. Studies in the Bible and the Ancient Near East, Qumran, and Post-Biblical Judaism. Edited by C. Cohen, A. Hurvitz and S. M. Paul. Winona Lake: Eisenbrauns, 2004.

Weinfeld, Moshe. Deuteronomy and the Deuteronomic School. Oxford: Clarendon, 1972. 
— and D. Seely. "Barkhi Nafshi." Pages 255-334 in Qumran Cave 4, XX. Poetical and Liturgical Texts, Part 2. DJD 29. Oxford: Clarendon, 1999. 